\title{
T-Cell Surface Glycoprotein CD4
}

National Cancer Institute

\section{Source}

National Cancer Institute. T-Cell Surface Glycoprotein CD4. NCI Thesaurus. Code

C16300.

T-cell surface glycoprotein CD4 (458 aa, $\sim 51 \mathrm{kDa}$ ) is encoded by the human CD4 gene.

This protein plays a role in antigen recognition and HIV entry. 